\title{
Forest resources and forestry in Vietnam
}

\author{
Tài nguyên rù̀ng và lâm nghiệp ở Việt Nam \\ Review paper
}

Luong, Thi Hoan*

Bac Giang Agriculture and Forestry University, Vietnam

\begin{abstract}
Forest and forestland are important roles and sources of livelihood for the population living in or near forests and in mountainous areas of Vietnam. The objectives of this paper analysed the change in forest resource, and policy of forestry in Vietnam. In recent several years, forest area rapidly covered an average rate of 240,000 ha/year and had about 13.39 million hectares in 2010. It has contributed to the use of bare land, job creation and improvement of livelihoods for $25 \%$ of Vietnam's population living in mountainous areas. Those results were the purpose of reforestation program and the production of wood industry in Vietnam. In this addition, government policies and regulations have provided a solid foundation for development of the forest plantations and conservation of forest ecosystems though forest land allocation and lease to organizations, households, and individuals. Therefore, the forest utilization has motivated by both environmental and commercial factors in Vietnam based on dividing into three forest categories special use, protection and production forests. However, the development strategy of forest management plan is the difficulties associated with conflicting land claims and boundary disputes due to the value of the established forest.
\end{abstract}

Rùng và đất rùng đóng vai trò quan trọng và là nguồn sinh kế cho nguời dân sống trong hoặc gần rùng ở các khu vưc miền núi của Việt Nam. Mục tiêu của nghiên cúu này phân tích sư thay đổi về tài nguyên rùng và chính sách về lâm nghiệp. Trong một vài năm gần đây, diện tích rùng bao phủ nhanh với tốc độ trung bình 240.000 ha/năm và có khoảng 13,39 triệu ha trong năm 2010 này đã góp phần vào việc sử dụng đất trống, tạo việc làm và cải thiện đời sống cho $25 \%$ dân số sống ở khu vực miền núi của Việt Nam. Kết quả này là mục đích của chuơng trình trồng rùng và sản xuát gố công nghiệp tại Việt Nam. Bên cạnh đó, chính sách và các quy định của chính phủ đã cung cấp một nền tảng vũng chắc cho việc phát triển diện tích trồng rùng và bảo tồn hệ sinh thái rùng mặc dù rùng và đất rù̀ng đã được giao và khoán cho các tổ chức, hộ gia đình, cá nhân. Vì vậy, việc sủ dụng rùng đã thúc đẩy bởi hai yếu tố môi truờng và thuơng mại ở Việt Nam, dựa trên phân loại rùng: rùng đặc dụng, rùng sản xuất và rùng phòng hộ. Tuy nhiên, chiến luợc kế hoạch quản lý phát triển rù̀ng có những khó khăn liên quan đến xung đột khiếu nại đất và tranh chấp biên giới do giá trị của rùng được thành lập.

Keywords: change in forest area, rehabilitation, ecosystems, plantation, management policy

\section{Introduction}

Vietnam extends from $8^{\circ} 50^{\prime} \mathrm{N}$ to $23^{\circ} 20^{\prime} \mathrm{N}$ along the southeastern margin of mainland South-East Asia and is a tropical monsoon country and complicates topography (Figure 1). The total natural land area in Vietnam is 33.12 million ha of which forests and forest land together cover about two thirds of the total land area (Jong et al., 2006). Therefore, forestry is an economic sector that is greatly influenced by socio-economic change in Vietnam (FAO, 2009). Although, Vietnamese forests are diversity and most of all are natural forests (Phuong et al., 2011), degrading forestland was caused by high population pres- sure that was exploited illegally logging forest, slashed and burned shifting cultivation.

At current, about over 85 million inhabitants belong to 54 ethnic groups of which 24 million people live in or near forests and depend on forest resources (MARD, 2007; FAO, 2009), with lifestyles of slash and burn shifting cultivation and wood exploitation. These lifestyles concentrate the majority of the people living in the uplands. In the uplands, forests account for $90 \%$ of Vietnam's forest cover (Hai, 2009). These forest resources are an important for both the livelihood of the populations resid- 
ing in the upland regions and downstream, and for the economic development of the country.

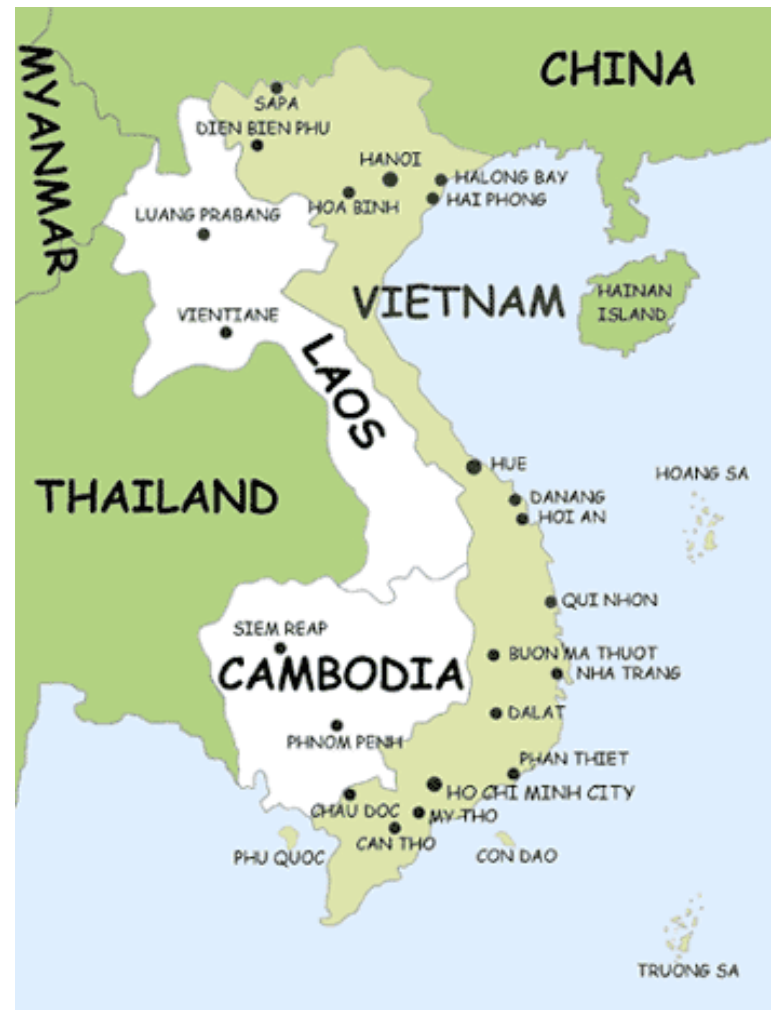

Figure 1. Vegetation map in Vietnam

(Source: FAO)

In 1943, Vietnam had 14.3 million hectares of natural forests, covering $43 \%$ of total land area of the country. Forest area reduced rapidly for 9.18 million hectares in 1990 (27.2\% of the total land area) (Nghia, 2003). Decreasing forest was caused by owing to long-lasting wars, shifting cultivation, and over-exploitation during the period 1980-1990, about 100,000 hectares of forest was lost each year (FAO, 2009). From 1990 to the present, the forest area has been increased because of the policy renovation "doi moi" in Vietnam, forest and forest land management have been allocated to the different entities. Therefore, to understand forest resources as well as forestry development, the objectives of this paper analyze the change in forest cover, forest rehabilitation and conservation, forest policy of Vietnam.

\section{Change in forest cover}

The quality and quantity of forests has decreased over the decades (1943-1990) due to a range of socio-economic causes and unsustainable management and use (MARD, 2007). By 1990, forest cover had decreased sharply to 9.18 million hectares, accounting for 27\% (MARD, 2011, 2007; FAO, 2009).

However, forest coverage changed rapidly in Vietnam during the period 1990-2010. Forest area increased from $27 \%$ in 1990 to $28 \%$ in 1995 . After 1995 , total forest area was increased to $12,616,000$ hectares and accounted for $37 \%$ of the total land area in 2005 (FAO, 2009). By the end of 2006, forest area in Vietnam was 12,874,000 hectares of which 10.41 million hectares were natural forest and 2.464 million hectares were plantation forest (MARD, 2007; FAO, 2009) and reached to $40 \%$ in 2010 (MARD, 2011) (Table 1).

Table 1. Changes in Vietnam's forest cover between 1943 and 2010

\begin{tabular}{|c|c|c|c|c|}
\hline \multirow{2}{*}{ Year } & \multicolumn{3}{|c|}{$\begin{array}{l}\text { Forest } \\
\text { area (ha) }\end{array}$} & \multirow{2}{*}{$\begin{array}{c}\text { Forest } \\
\text { cover } \\
(\%)\end{array}$} \\
\hline & Total area & Plantation & $\begin{array}{c}\text { Natural } \\
\text { forest }\end{array}$ & \\
\hline 1943 & $14,300,000$ & & $14,300,000$ & 43 \\
\hline 1976 & $11,169,000$ & 92,000 & $11,077,000$ & 33 \\
\hline 1980 & $10,608,000$ & 422,000 & $10,486,000$ & 32.1 \\
\hline 1985 & $9,892,000$ & 584,000 & $9,308,000$ & 30 \\
\hline 1990 & $9,175,000$ & 745,000 & $8,430,000$ & 27 \\
\hline 1995 & $9,305,000$ & $1,050,000$ & $8,252,000$ & 28 \\
\hline 1999 & $10,916,000$ & $1,471,000$ & $9,444,000$ & 33.2 \\
\hline 2002 & $11,785,000$ & $1,919,000$ & $9,865,000$ & 35 \\
\hline 2003 & $12,095,000$ & $2,090,000$ & $10,055,000$ & 36 \\
\hline 2004 & $12,306,000$ & $2,218,000$ & $10,008,000$ & 36.7 \\
\hline 2005 & $12,616,000$ & $2,333,000$ & $10,283,000$ & 37 \\
\hline 2006 & $12,874,000$ & $2,464,000$ & $10,410,000$ & 38 \\
\hline 2010 & $13,388,075$ & $3,083,259$ & $10,304,816$ & 39.5 \\
\hline
\end{tabular}

Sources: Jong et al., 2006; MARD, 2007; FAO, 2009; MARD, 2011

Of the total area of plantation forest, stocked forest constituted 1,059,083 ha, non-stock forest (young forest) $1,104,984 \mathrm{ha}$, bamboo $81,307 \mathrm{ha}$, and non-wood forest 218,336 ha in 2006 (FAO, 2009). Forests are classified into three forest types including special-use, protection and production forests (Figure 2) as defined by the Forest Protection and Development Law in 1991. Until 2010, total forest area was 13.39 million hectares (of which 1.93 million hectares special use forest, 6.2 million hectares of protection forest and 5.3 million hectares of production forest were coverage) (MARD, 2011).

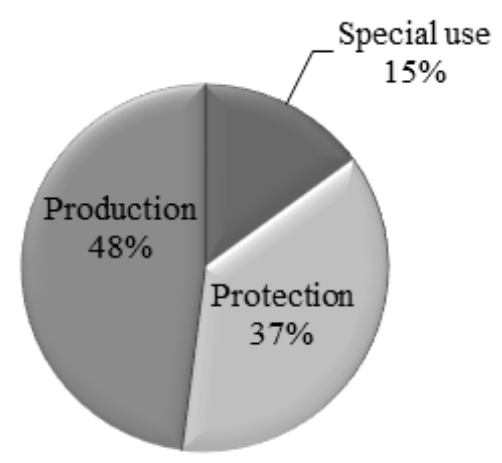

Figure 2. Proportion of different types of forests by area (ha)

Source: Forest Protection Department, 2010

The reasons of increasing forest areas were the results of forest protection and rehabilitation program as well as improvement of not only the ecology system but also the structure, productivity and other protective functions. In addition, change in forest cover was resulted by Vietnam's government programs which have given to plantation planning. It has contributed to the use of bare land, job creation and improvement of livelihoods for $25 \%$ of Vietnam's population living in or near forests and in 
mountainous areas (FAO, 2009). Therefore, the implement for functional change of forest area has been mainly done for mountainous areas and ethnic minorities. However, high rates of population growth, free immigration and ineffective use of agroforestry results in pressure on forest and expansion of agricultural land.

\section{Forest rehabilitation and conservation}

The main target for forest rehabilitation is unused hilly land and an important part of protection and special use forest areas. In 2007, the unused land of the entire country was 6.76 million ha, of which barren land on hilly and mountainous area was 6.16 million ha, equivalent to $18.59 \%$ of the total national area (MARD, 2007). Almost bare land and denuded hills were concentrated mainly mountainous regions of the country (Jong et al., 2006; MARD, 2007). Between 2000 and 2005, the forest rehabilitation area increased at an average rate of 240,000 ha/year (FAO, 2009). The area of forest rehabilitation including natural forest and young forest was about $7,774,268$ ha of which newly rehabilitated young forest was approximately 3 million ha (Jong et al., 2006).

However, in rehabilitation program, the government has supported the finance to individuals, households, organizations who planted the new forest and contracted for assisted natural regeneration, protection and special use forests (GOV, 1998). The support of finance depends on each forest types and topography condition such as for new planting forest, the government supports about 100120 dollars per ha. For protection forest and special use forest, the government supports about 50 dollars per year. In general, financial efficiency of the State support is low and the attractiveness to households and investors is limited, but plantations have provided profits for foresters and encouraged local people to invest in planting in area with sustainable demand. Enhancement of rehabilitation and development of natural forest, and plantation through application of silvicultural measures with multi-purpose species, planting fast-growing species, and non-wood forest products aim to improve the quality of forests and the income of forest dependent people.

However, for forest protection and conservation, Vietnamese government must be based the development principle and has established 128 special use forest areas covering 2,228,149 hectares and accounting for $11.7 \%$ of total forestry area to maintain and protect the ecosystem and its biodiversity (FAO, 2009). There are 30 national parks $(966,127 \mathrm{ha}), 60$ nature reserves $(1,114,128 \mathrm{ha})$ and 38 landscape protection areas $(147,894 \mathrm{ha})$ in the special use forest system until 2009 (Table 2) (Jong et al., 2006; FAO, 2009). In addition, the Vietnam government has promulgated a series of legislative instruments including the Law on Environment Protection (2005), the Law on protection and Development of Forest (1991, 2004) for protecting biodiversity.
Table 2. Vietnam s special use forest status

\begin{tabular}{lcc}
\hline Category & $\begin{array}{c}\text { Amount } \\
\text { (No.) }\end{array}$ & $\begin{array}{c}\text { Area } \\
\text { (ha) }\end{array}$ \\
\hline I. National Park & 28 & 966,127 \\
\begin{tabular}{l} 
II. Nature Reserve Area \\
$\begin{array}{l}\text { III. Protected landscape or } \\
\text { seascape area }\end{array}$ \\
\hline Total
\end{tabular} & 62 & $1,114,128$ \\
\hline Source: Jong et al., 2006; FAO, 2009 & 128 & $2,228,149$ \\
\hline
\end{tabular}

\section{Forest utilization}

Based on the land laws of 1993 and 2003, the State handed over forest and land use rights to forest owners via forest and land allocation and lease, recognition of forest and land use rights for those using land in stable manner or ownership rights over planted production forests. Forestland use rights are 50 years and can be possible extension. Until January 2006, State owned forest and forestland amounted to $10,940,379$ ha $(76 \%$ of total forest and forest land area), households, individuals and the private sector owned forest area calculated to 4,787,762 ha $(24 \%$ of the total land area) (FAO, 2009). The remaining area belonged to community, cooperative and joint venture enterprises. There were 1,180,465 forestland owners, including 1,173,829 households and individuals, 1,245 commune people's committees, 1,365 economic organizations, 3,105 other entities in addition to a number of enterprises involved in joint ventures with foreign partners and enterprises with foreign investment (Jong et al., 2006; FAO, 2009; MARD, 2007). Changes in forest ownership and utilization have not only been reflected in changes in the structure of forest and land utilization but have also resulted in the establishment of a nationwide forest owner system. Therefore, the forest utilization has motivated by both environmental and commercial factors in Vietnam. For example, the rate of export value of timber and non-timber forest products increased from 60.5 million USD in 1996 to over 2000 million USD in 2006 (MARD, 2007) (Table 3).

Table 3. Vietnam's forest product exports between 1996 and 2006

\begin{tabular}{cc}
\hline Year & $\begin{array}{c}\text { Value of exports } \\
\text { (million USD) }\end{array}$ \\
\hline 1996 & 60.5 \\
1998 & 108.1 \\
2000 & 219.3 \\
2001 & 344 \\
2002 & 435 \\
2003 & 567 \\
2004 & 1054 \\
2005 & 1570 \\
2006 & 2000 \\
\hline
\end{tabular}

Source: MARD, 2007

Although forest area increased rapidly, the quality of forest has fallen especially decreasing the average volume of forest because new reforestations are juveniles. In addition, higher demand for forest products puts pressure on forest resources and especially natural forests. At cur- 
rent, the demand for forest products exceed sustainable supply and the area of high yield forest plantation remains limited and fragmented. Annual harvesting from forest products was 2.7 million $\mathrm{m}^{3}$ of which $200,000-300,000$ $\mathrm{m}^{3} /$ year timber and non-timber exploited from natural forests, and 2.0-2.5 million $\mathrm{m}^{3}$ from plantation forests (Jong et al., 2006; MARD, 2007). Annual forest products have contributed about 2-3\% of total GDP in whole country, and reduced $70 \%$ of the number of poor households for forest dependent people in key forest area (Sunderlin \& $\mathrm{Ba}, 2005)$. However, with respect to plantation forests, seedling development and intensive plantation techniques have resulted in increasing forest growth rates. The average productivity of tissue culture based eucalyptus plantations increased from $8-10 \mathrm{~m}^{3} /$ ha/year and acacia plantations attained $20-25 \mathrm{~m}^{3} /$ ha/year (MARD, 2007; FAO, 2009). This was the result of development of technique systems such as tree breeding improvement, assisted silvicultural technique, and management practice. However, the competitiveness of forest product production remains low and international integration is creating both opportunities and challenges for forest product processing and trade.

\section{Main forest ecosystems}

Vietnam's topography, climate and soils combine to produce extremely diverse and abundant forest vegetation. Forest types of the monsoon tropics have been a wide range in Vietnam. Majority of tropical forest is mixed forest species, primary or less affected mixed forest species that are very necessary for biological productivity prediction (Phuong et al., 2011). These ecosystems only distribute in nature reserve area, national parks, remote and isolated areas, mountainous areas. The dominant forest formations include evergreen closed tropical rain forest, semi-deciduous closed tropical humid forest, evergreen broad leaved forests on limestone, natural needle leaved forests, dry dipterocarp forest, mangrove forest, melaleuca forests, and bamboo forests (FAO, 2000). These forest ecosystems are distributed at the different elevations. Example for, the ecosystems of evergreen forests, semi-deciduous forest have distributed at an elevation of less than $700 \mathrm{~m}$ in the north and less than $1,000 \mathrm{~m}$ in the south, at the elevation of 2,400-2,900 $\mathrm{m}$ for natural needle leaved forests, and $600-900 \mathrm{~m}$ for dry dipterocarp forest.

In general, the vegetations of these forest ecosystems are very diversified, abundant and often distributed in all provinces of the whole country. There are around 19,357 plant species and about 295 animal species (Nghia, 2003; Phuong et al., 2011). Of plant species investigated, forest ecosystems accounted for about $30 \%$ of plant species in the north and about $25 \%$ of the total number of plant species across the country, at least 1,000 tree species reach large size, 354 species of trees can be used for commercial timber production (Phuong et al., 2011). The bamboo species in Vietnam is very rich, in which at least 40 species have commercial value. The abundance of species has given Vietnam's forests to be tremendous value in economics and science.

\section{Forest policy and management}

Vietnamese government has a number of policies that directly impact development of forestry. Those polices maintain and improve forestry development sustainability following the Land Laws (1990; 2003 \& 2013), Forest protection and Development Law (1991 and 2004), and The Environment Protection Law $(2005 ; 2014)$ and some Decisions such as Decision 139 in 2004 imposed administrative fines in protection and management of forestland and forest resources, Decision 17 in 1992 codified a list of endangered species banned from harvesting or hunting, Decision 08 in 2001 provided a legal framework for management of production protection and special use forests, Decision 178 in 2001 created guidelines for benefit sharing of revenues derived from forestland and forest resources, and Decision 192 in 2003 created a protected area management strategy until 2020 (Quyen \& Nghi, 2011). The key policy framework was developed by Laws and Decisions to promote the development of plantation and production of wood in the country. Under this framework, the government's Decree 02 issued in 1996 stipulates the allocation of forestland to individual households and other groups for production purposes. This Decree serves as a foundation for households to establish their plantation forests.

To enable appropriate forest management and use in accordance with the law on forest protection and development, forest in Vietnam was divided into three main categories: protection, special use and production forest (Figure 2). Based on forest types, forestland management regimes divided three levels of management including State, private and community management (Figure 3) (Tuan, 2006).

- State management has been consisted to management actors for special use and protection forest management boards and forest enterprises.

- Private management includes land users for households and individuals and joint venture enterprises and organizations management.

- Community management is managed by actors such as village, forest user groups and types of forestland are traditional village forests, forests and forestlands unofficially allocated and contracted by local authorities.

The role of the State hand over forest use rights through forest allocation and lease. The Ministry Agricultural and Rural Development are responsible to the government for nationwide forest management, protection, and development. The government regulates organizational structure, task and authorities of professional forestry agencies from the central to district level and working in forestry communities, towns and in large forest areas. General trends as regards forest policies and legislation have developed (Figure 4). 


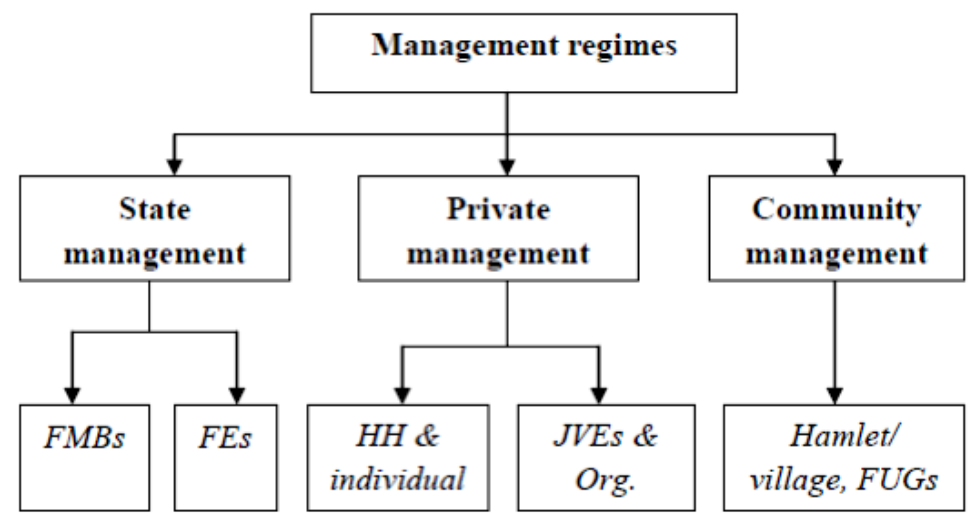

Figure 3. Forest management regimes in Vietnam. FMBs (Forest Management Broads), FEs (Forest Enterprises), HH (households), JVEs (Joint Venture Enterprises), Org (organization), and FUGs (Forest User Groups). Sources modified from Tuan 2006

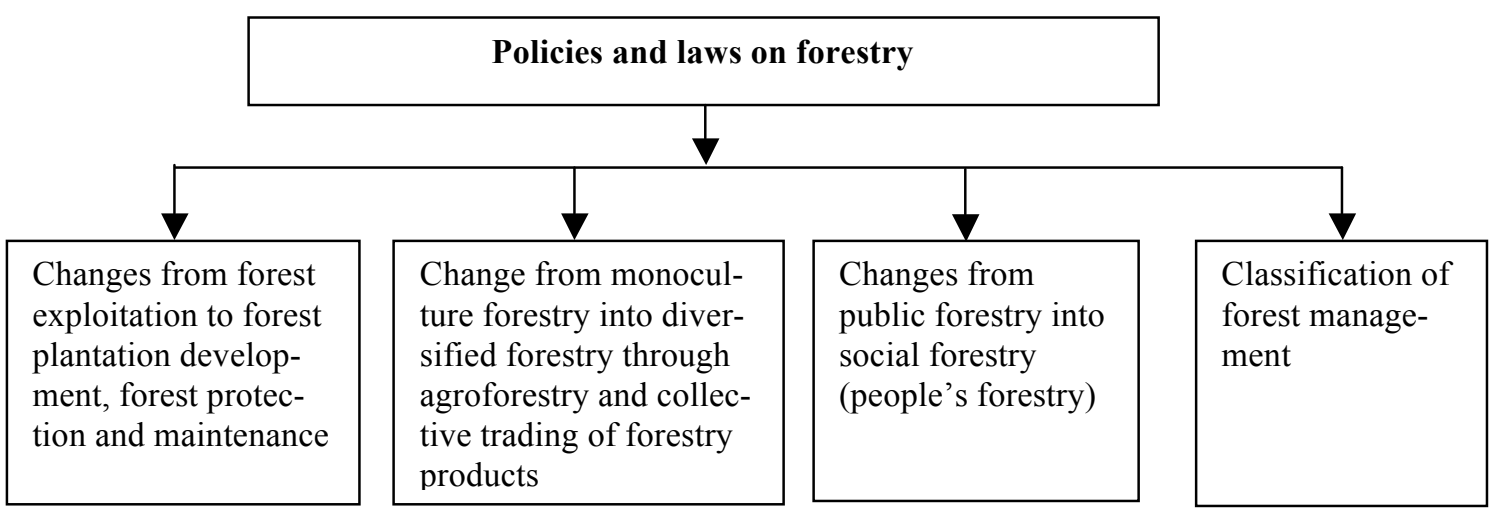

Figure 4. Trends in Forestry laws and policies

In the end of 2009, 13.3 million hectares of forests of Vietnam was managed by eight forest user groups: management board, households, people's committees, state company, organizations, economic entities, army and the community (Figure 5; Table 4). The three biggest user groups in terms of forest area under their control were management board (MB), households, and people's committee (Table 4). This result had been paid attention to sustainable forest management by the government in general and the forestry sector in particular. For example, forest management in 2005 (Table 5) was the results of enforcement of national policy. Currently, land allocation is approximately $50 \%$ complete in the country and is progressing more slowly than expected due to difficulties associated with conflicting land claims and boundary disputes (FAO, 2009). This is especially the case in forest areas where inventories often have to be conducted before allocation takes place due to the value of the established forest. However, government policies and regulations have provided a solid foundation for development of the forest plantations, conservation forest, and the production of wood industry in Vietnam.

Table 4. Forest area managed by forest user groups on 31 December 2009

\begin{tabular}{|c|c|c|c|c|}
\hline Forest user group & Main forest types managed & $\begin{array}{r}\text { Natural } \\
\text { forest (ha) }\end{array}$ & $\begin{array}{l}\text { Plantation } \\
\text { forest (ha) }\end{array}$ & $\begin{array}{r}\text { Total } \\
\text { forest (ha) }\end{array}$ \\
\hline Management broad & Special use \& protection forests & $3,818,178$ & 499,774 & $4,318,492$ \\
\hline State company & Protection \& production forests & $1,55,473$ & 492,779 & $2,044,252$ \\
\hline Other economic entities & Protection \& production forests & 27,219 & 64,318 & 91,537 \\
\hline Army & Protection forest & 196,027 & 47,661 & 243,689 \\
\hline Household & $\begin{array}{l}\text { Mainly production forest with } \\
\text { poor quality }\end{array}$ & $1,961,517$ & $1,325,553$ & $3,287,070$ \\
\hline Community & $\begin{array}{l}\text { Mainly production forest; some } \\
\text { protection forest }\end{array}$ & 171,395 & 19,989 & 191,383 \\
\hline Other organization & Protection \& production forest & 575,378 & 84,556 & 659,935 \\
\hline People's committee & $\begin{array}{l}\text { Mainly production forest in } \\
\text { remote areas }\end{array}$ & $2,037,578$ & 384,907 & $2,422,485$ \\
\hline Total (ha) & & $10,339,305$ & $2,919,538$ & $13,258,843$ \\
\hline
\end{tabular}

Source: Forest Protection Department, 2010; Quyen \& Nghi, 2011 


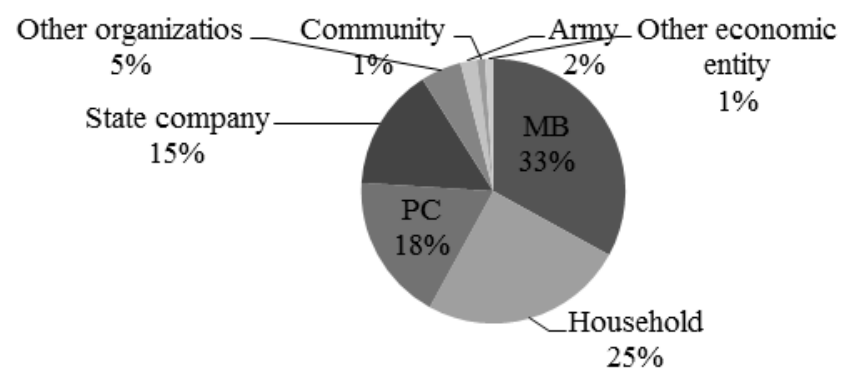

Figure 5. Proportion of forest areas managed by forest user groups: MB (management board), PC (People's committee). Source (Forest Protection Department, 2010)

Table 5. Forest management in Vietnam

\begin{tabular}{|c|c|c|c|}
\hline No & Name & Unit & Vietnam \\
\hline \multirow[t]{10}{*}{1} & Forests resources & & \\
\hline & Total forest area & Million ha & 12.616 \\
\hline & Forest cover & $\%$ & 37 \\
\hline & Forest area/ person & $\mathrm{Ha} /$ person & 0.15 \\
\hline & Changes in total forest area & $\% /$ year & 1.9 \\
\hline & Total volume & Billion $\mathrm{m}^{3}$ & 0.691 \\
\hline & Average volume & & \\
\hline & Natural forest & $\mathrm{m}^{3} / \mathrm{ha}$ & 76.5 \\
\hline & Plantation forest & & 40.6 \\
\hline & Average volume/person & $\mathrm{m}^{3} /$ person & 8.4 \\
\hline \multirow[t]{3}{*}{2} & Biodiversity & & \\
\hline & Special use forest area & Million ha & 1.93 \\
\hline & $\%$ special use forest & $\%$ & 15.20 \\
\hline \multirow[t]{6}{*}{3} & Production function & & \\
\hline & Total production forest area & & 4.48 \\
\hline & - Natural forest & Million ha & 3.106 \\
\hline & - $\quad$ Plantation forest & & 1.382 \\
\hline & (2007) in natural production forest area & $\% /$ year & -0.33 \\
\hline & (2007) in plantation production forest area & $\% /$ year & 9.74 \\
\hline \multirow[t]{5}{*}{4} & Protection function & & \\
\hline & Protection forest & & 6.20 \\
\hline & - Natural forest & Million ha & 5.33 \\
\hline & - Plantation forest & & 0.87 \\
\hline & $\%$ protection & $\% /$ year & 12.65 \\
\hline \multirow[t]{2}{*}{5} & Socio-economic function & & \\
\hline & Timber exploitation & Million $\mathrm{m}^{3} /$ year & 2.7 \\
\hline
\end{tabular}

Source (FAO, 2009)

\section{Conclusion}

The forest area in Vietnam amounted to 13.3 million hectares consisting of 1.93 million hectares special use forest, 6.2 million hectares of protection forest and 5.3 million hectares of production forest in 2010. Forest area increased rapidly during the 1990-2010. This was the results of forest protection and rehabilitation programs as well as a series of legislative instruments (the Laws on Land, the Law on Environment Protection, and the Law on protection and Development of Forest) of Vietnamese government. Forest contributed a remarkable job creation and improvement of livelihoods for Vietnam's population living in or near forests and in mountainous areas. Increasing forest area was the success of rehabilitating forest degradation rate and the purpose of increasing wood production from forest plantation through genetic devel- opment and silvicultural techniques. On the other hand with complicated topography condition, Vietnam's tropical forest is species abundance and high biodiversity, which formed diversifying forest ecosystems. To guarantee the individuals, households, local communities, and organization's active participation in sustainable forest management practice, the government has empowered the individuals, households, local communities, and organization that have been allocated and contracted on forestland, and have the owned rights on their land. The government also supported the individuals, households, local communities, and organization to participate in plantation programs.

However, the forestry development strategy in Vietnam between 2010 and 2020 is to manage, protect, and develop 16.24 million hectares of forest and forest land, in- 
creasing the forest cover $47 \%$ and $20-24$ million $\mathrm{m}^{3} /$ year of wood production (FAO, 2009; MARD, 2007). To meet requirements, major investment will be necessary each year. Infrastructure for forest plantation development will also require significant investment and it may therefore prove difficult to achieve sufficient supply to meet domestic demand in 2020. The implementation of forest and land allocation and lease policies targeted at households, communities, and individuals is forecast to create 2 million new jobs in the forest sector and provide additional jobs in mountainous communities through tree planting, tending, protecting, harvesting and forest product processing activities. Sustainable harvesting and utilization of natural forests should be based on an appropriate forest management plan.

\section{References}

[1] FAO. (2009) Vietnam forestry outlook study. AsiaPacific forestry sector outlook study II. Working papers No APFSOSII/WP/2009/, Food and Agriculture Organization of the United Nations Regional Office for Asia and the Pacific, Bangkok. 1-71.

[2] Forestry Department Food and Agriculture Organization of the United Nations. Global forest fire assessment. Rome (2001) 1990-2000 http://www.fire.uni-freiburg.de/programmes/un/fao/ Wp55_eng.pdf

[3] Government of Vietnam (GOV) (1998) The Decision No.661/QD-TTg on objectives, tasks, policies and organization for the establishment of five million hectares of new forest. 29 July 1998.

[4] Hai, N.T. (2009) Human ecological analysis of land and forest use by the Hmong people for harmonising with the governmental reforestation program in Vietnam. PhD Dissertation -652259480. Technique University Dresden.

[5] http://luatvietnam.vn/default.aspx?tabid $=651 \& \mathrm{id}=58$ 914700-4627-413c-ba250a833af9dc5c\&rurl=\%2fVL $\% 2$ f667\%2fNghi-dinh18HDBT-cua-Ho-dong-Bo-truong-ve-viec-quydinh-danh-muc-thuc-vat-rung-dong-vat-rung-quyhie\%2f58914700-4627-413c-ba25- 0a833af9dc5c\%2fdefault.aspx.

[6] http://thuvienphapluat.vn/archive/Luat-bao-ve-moitruong-2014-vb238636.aspx.

[7] http://huvienphapluat.vn/archive/Nghi-quyet-452013-QH13-dieu-chinh-Chuong-trinh-xay-dungluat-phap-lenh-vb197301.aspx.

[8] Jong, V.D, Sam, D.D, Hung, T.V. (2006) Forest rehabilitation in Vietnam: Histories, realities and future. Central and International Forest Research JI. CIFOR, Situ Gede, Sindang Barang Bogor, Barat 16680, Indonesia, ISBN 979-244652-4.

[9] MARD (Ministry of Agriculture and Rural Development) (2007) The Decision No. 18/2007/QD-TTg Vietnam Forestry Development Strategy 2006-2020. 5 February 2007.

[10] MARD. (2011) Report on the implementation result of the five million hectare new afforestation project and the forest protection and development program in the 2011-2020 periods. No 243, 26th October 201Nghia, N.H. (2003) Conservation of Forest Genetic Resource in Vietnam. The XII World Forestry Congress, Quebec City, Canada.

[11] Phuong, V.T., Lung, N.N., Sam, D.D., Quat., N.X., Lien, T.V., Que, N.D., Con, T.V., Ky, N.D., Cam, L.V., Thu, D.H., Giang, N.T., Anh, H.V., Giang, D.T., Thanh, P.N. (2011) Final report on forest ecology stratification in Vietnam. The UN-REDD Programme.

[12] Quyen, N.T., Nghi, T.H. (2011) How Vietnam is prepared to meet legal requirement of timber export markets. Tropenbos International Vietnam, Hue City, Vietnam.

[13] Sunderlin, W.D., Ba, H.T. (2005) Poverty Alleviation and Forests in Vietnam. Center for International Forestry Research. P.O. Box 6596 JKWB, Jakarta 10065, Indonesia.

[14] Tuan, D.A (2006) Governance Structure and Performance A comparative Institutional Analysis of Community Forest Management Case study of Hoa Binh Province, Vietnam. PhD Thesis Dresden University of Technology. NSBN 3-9809816-5-7. 